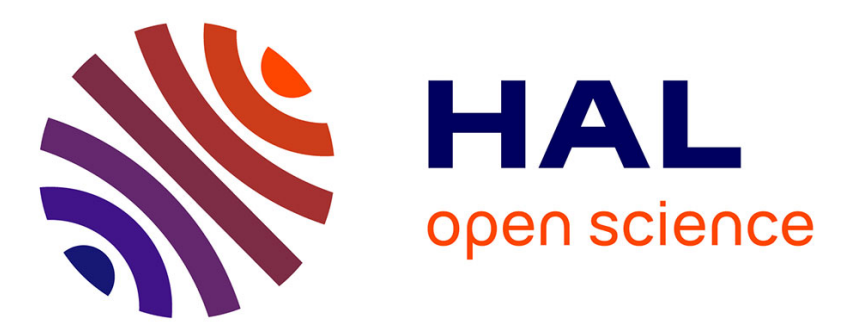

\title{
Cadmium in soils and cereal grains after sewage-sludge application on French soils. A review
}

Denis Baize

\section{To cite this version:}

Denis Baize. Cadmium in soils and cereal grains after sewage-sludge application on French soils. A review. Agronomy for Sustainable Development, 2009, 29 (1), pp.175-184. hal-00886468

\section{HAL Id: hal-00886468 https://hal.science/hal-00886468}

Submitted on 1 Jan 2009

HAL is a multi-disciplinary open access archive for the deposit and dissemination of scientific research documents, whether they are published or not. The documents may come from teaching and research institutions in France or abroad, or from public or private research centers.
L'archive ouverte pluridisciplinaire HAL, est destinée au dépôt et à la diffusion de documents scientifiques de niveau recherche, publiés ou non, émanant des établissements d'enseignement et de recherche français ou étrangers, des laboratoires publics ou privés. 


\title{
Cadmium in soils and cereal grains after sewage-sludge application on French soils. A review
}

\author{
Denis BAIZE* \\ INRA, UR0272, Science du Sol, Centre de recherche d'Orléans, BP 20619, 45166 Olivet Cedex, France
}

(Accepted 29 May 2008)

\begin{abstract}
Recycling sewage sludges as fertilisers on soils for crop production has several potential benefits such as providing large amounts of phosphorous and organic matter. However, the spreading of urban sewage sludge is a constant cause of controversy because it is known to introduce potentially toxic trace metals into the soil, particularly cadmium. In order to clarify this debate, this review article presents a synthesis of the results of several studies carried out in France on the impact of sewage-sludge spreading. This article reports mainly Cd results but also some results on other trace metals such as $\mathrm{Cr}, \mathrm{Cu}, \mathrm{Hg}, \mathrm{Ni}, \mathrm{Pb}$ and $\mathrm{Zn}$. Two kinds of data are presented: (1) soil data including total metal contents and data from partial extraction to evaluate the phytoavailable fractions, and (2) plant data including metal content of wheat, a major agricultural crop. The field experiments involved very different amounts of applied sewage sludges and $\mathrm{Cd}$. Indeed, three categories of experiments stand out, the first and second involving high amounts of applied Cd, and the third involving low amounts of applied Cd: (1) during the 1970s and '80s, sludges with a high trace metal content, especially Cd, were spread at the INRA trials at Couhins experimental farm on sandy soils and in the Vexin area on silty topsoils. The quantities of applied Cd were very high, ranging from $3600 \mathrm{~g}$ to $641000 \mathrm{~g}$ per ha. Here, the results show a notable impact on total Cd contents of topsoil and cereal grains. (2) Sludges containing high levels of industrial cadmium were spread on acid soils in the Limousin region for more than twenty years up to 1998. Topsoil Cd contents were measured in fields where the cadmium input was highest, of 300 to $600 \mathrm{~g} \mathrm{Cd}$ per ha. Here, a clear increase in the Cd content of cereal grains was found. (3) During the 1990s and 2000s, numerous experiments with sewage-sludge applications compatible with the new French regulations of 1998 were implemented. The amounts of applied Cd were therefore much lower, from 0.6 to $270 \mathrm{~g} / \mathrm{ha}$. Here, no impact was detected on the composition of cereal grains. This review article concludes that the application of huge quantities of sewage sludges in the 1970s and '80s had a clear and long-lasting effect on both soil and grain Cd compositions. Nonetheless, spreading sewage sludge in accordance with the new French regulations had no significant impact on soil and cereal-grain Cd concentrations.
\end{abstract}

cadmium / cereal grains / phytoavailability / sewage sludge / soil / total content

\section{INTRODUCTION}

Trace metals - cadmium, chromium, copper, mercury, nickel, lead, zinc, etc. - are unwanted though often unavoidable constituents of urban sewage sludge. As some of these metals, such as $\mathrm{Cd}, \mathrm{Pb}$ and $\mathrm{Hg}$, are potentially toxic and have no agronomic interest (Wani et al., 2007; Wahid et al., 2008), their presence generates a certain worry in France as well as in all of Europe (Cattani et al., 2008). This is perfectly understandable as some sludge is spread over soil destined for growing food. However, the term "sludge" covers a multitude of different compositions, depending on whether such residue comes from a small, rural, water-treatment plant or from a huge plant in an industrial conurbation. This illustrates the im-

*Corresponding author: denis.baize@orleans.inra.fr portance of knowing the exact origin of the sludge and its trace metal concentrations.

Going far beyond the European directive 86/278/CEE, the new French regulation of 1998 firmly urges the sludge producers to improve the quality of their by-product. The two main points of this new ordinance were (i) the lowering of the maximum metal contents in the sludge to be spread: for instance, the maximum cadmium content of sludge was $20 \mathrm{mg} / \mathrm{kg}$ DM until 01/01/2001, then $15 \mathrm{mg} / \mathrm{kg}$ until 01/01/2004 and only $10 \mathrm{mg} / \mathrm{kg}$ since this date, and (ii) the limitation of the metal fluxes applied on farmlands over a 10 year period (see Tab. IV).

Fortunately, the efforts of the past 30 years in this field have borne fruit, as all total trace metal contents in sludge have steadily decreased over time, particularly for cadmium 


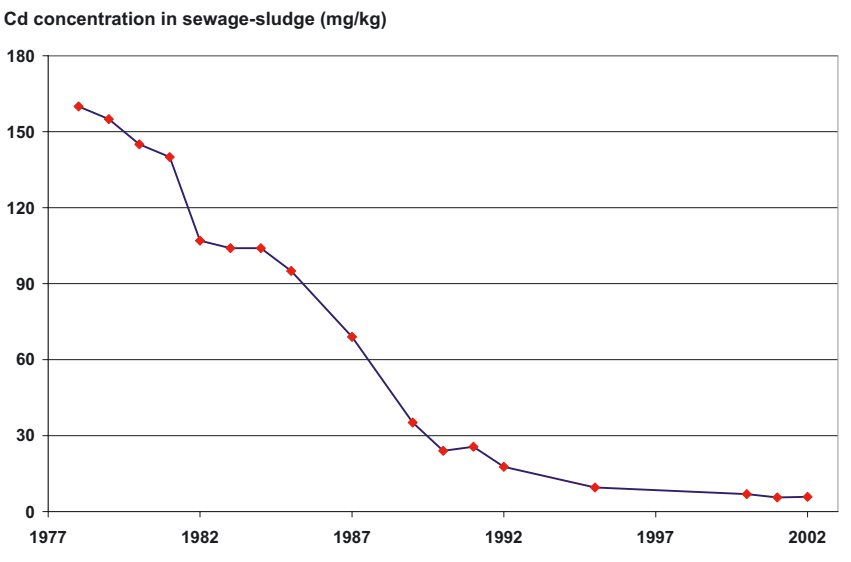

Figure 1. Mean annual cadmium concentrations from 1978 to 2002 in sludge from the treatment plant of waste-waters of Greater Paris (in Achères). This concentration has decreased strongly over time from 160 to $5.8 \mathrm{mg} / \mathrm{kg} \mathrm{DM}$.

(Fig. 1). Such efforts should continue without respite, so as to reduce the input of metals into agricultural land as much as possible.

Other questions are: what happens to these trace metals once they have been spread on soil? How much do the chemical forms in which these metals occur - and their carrier phases - change over time, when comparing newly spread sludge with 5- to 10 year-old residues (McGrath et al., 2000; Bergkvist et al., 2003)? Which constituents of the receiving soils, such as iron and manganese oxides, clay minerals and organic matter, will immobilise such metals? And, in that case, will the indefinite progressive accumulation of such metals not have a harmful effect in the short to medium term, i.e. 20-100 years, such as the transfer of metals into plants, i.e. into our food chain (phytoavailability)? Or will, on the contrary, such metals migrate rapidly toward groundwater, because of their high mobility, or toward surface water through runoff and transport of solid particles?

Finally, must we fear a "time bomb" effect in the medium to long term, i.e. the release of initially immobilised metals under the influence of a major environmental change, such as the progressive acidification of soil abandoned by agriculture?

Hereafter, the results are presented of several experiments, most of which focused on soft wheat. They derive from studies carried out in France by various research institutions and/or Agricultural Chambers. Their common objective was to evaluate the impact of the spreading of sludge from urban wastewater treatment plants under different conditions of composition and volume.

An exhaustive paper on this subject was published in the “Courrier de l'Environnement de l'INRA" (Baize et al., 2006), presenting the protocols and main results of numerous French experiments, in particular the most recent ones, studying the impact of urban sewage sludge.

In the present paper, we refer especially to the older and better known studies that are most often mentioned. In addition, we discuss in particular cadmium $(\mathrm{Cd})$, as this is one of the most toxic trace metals, as well as being among the most mobile and phytoavailable ones. Like mercury and lead, the presence of cadmium is highly dependent upon human agricultural and industrial activities. Except for some well-known and well-localised anomalies, its natural pedogeochemical concentrations generally are very low, around 0.10 to $0.15 \mathrm{mg} / \mathrm{kg}$ in surface horizons, though human input from various sources can easily triple or quadruple such values (Baize et al., 1999).

\section{INDICATORS FOR IMPACT ASSESSMENT}

In order to estimate the impact of sewage-sludge application, three kinds of rather simple tools are often available:

(i) the total metal concentrations determined in topsoil samples;

(ii) the easily phytoavailable quantities as assessed by "partial" (also known as "single") extractions applied to the same topsoil samples;

(iii) the metal composition of plants cultivated on these soils, especially cereal grains (maize, barley and wheat), the latter being a major product in the human food chain that is of vital importance for the French economy.

\subsection{Total trace element contents in soil and soil-plant transfer}

In order to be representative of a truly "total" content, an analytical process must be able to extract all chemical forms of the element to be assayed, including those in the silicate lattices. It is thus necessary to use X-ray fluorescence or very strong dissolution methods, such as that using hydrofluoric acid (AFNOR, 1996) or alkaline fusion.

Total contents are measurements of stocks at a given time. The repetition of such measurements over different periods at the same point monitors the content and identifies any changes. In contrast with partial or sequential extractions, total contents today are routinely and easily determined and pose no problems of interpretation, regardless of the soil sample properties such as $\mathrm{pH}$, particle size, presence of carbonates and of iron and manganese oxides, etc. (e.g. Nirel and Morel, 1990; Tack and Verloo, 1995; McBride et al., 2006). Unfortunately, total-content methods do not distinguish the chemical species, which means that such analyses provide no information about the mobility of the element in the soil, nor of its availability or toxicity toward living organisms (e.g. Rieuwerts et al., 1998a).

As a general rule, there is no direct relationship between the total content of a trace element in the soil and the quantity of this element absorbed by a plant (e.g. Rieuwerts at al., 1998b; Meers et al., 2005). In addition to the chemical forms in which each trace metal occurs, plant absorption is determined by certain soil properties, such as the $\mathrm{pH}$ or the abundance of constituents that can easily retain metals, as well as by the physiological and genetic specifics of the plants. Once absorbed by roots, trace metals can accumulate in the roots or move to other parts of the plant, e.g. leaves, stems or grains, where they are stocked. Each plant species has its proper strategy concerning such trace metal absorption and transfer phenomena. 


\subsection{Trace element determination in plant organs and "partial" extraction}

In order to know whether urban-sludge spreading has an impact on the composition of plant organs that are consumed, it is necessary to assay trace metal contents directly in these organs, such as wheat or maize grains, spinach leaves, potatoes, etc. In addition, it is needful to know the concentrations of such metals in the same crops during "normal" agriculture, i.e. without sludge spreading. To obtain such references, the AGREDE-QUASAR $^{1}$ (Baize et al., 2003) and GESSOL-La Châtre ${ }^{2}$ (Baize and Tomassone, 2003) research programmes were set up. These studies on the composition of agricultural products are indispensable for obtaining reliable answers to these questions and they must consider not only the plant species and the cultivar, but also past agricultural practices as well as soil types, which are highly varied in France.

The simplest method for defining trace metal species in soil uses chemical reagents that dissolve part of the metals in an air-dried soil sample sieved at $2 \mathrm{~mm}$. After this, the metals thus extracted are assayed. In the case of such "partial", also called "selective", extraction, a single reagent is used and the searched-for speciation is essentially "functional" (Ure, 1991; Bermond, 1999). The aim is to extract only the trace metal forms of interest, i.e. the potentially "mobile" or "phytoavailable" ones, through a judicious choice of the reagent and the operating conditions.

However, this approach of assessing phytoavailability by using partial extraction faces major theoretical objections. It is somewhat presumptuous to try to simulate absorption by means of an instantaneous chemical reaction, in vitro, between a reagent and a dried and sieved soil sample. Absorption is a biochemical reaction that occurs at the interface between the soil solution and the roots of a plant, over a period that can take several months while the plant grows. Another problem is that several methods exist for such assaying work, the protocols (and thus the results) of which are difficult to compare. No method seems to be universal, i.e. valid for all soil types, all elements and all plants.

\section{SPREADING HUGE VOLUMES OF SLUDGE WITH HIGH TRACE ELEMENT CONTENTS DURING THE 1970s AND 1980s}

\subsection{Sludge from the Achères plant ${ }^{3}$ spread in the Vexin area}

Sludge with a high trace metal content from a large wastewater treatment plant in Achères (see Fig. 1) was spread

\footnotetext{
${ }^{1}$ INRA Programme "Agriculture et épandage de déchets urbains et agro-industriels. QUAlité des Sols Agricoles et des Récoltes (Agriculture and spreading of urban and agrobusiness sludge. Quality of agricultural soil and crops)".

${ }^{2}$ Programme of the French Ministry for the Environment entitled "Fonctions environnementales des sols et gestion du patrimoine sol (Environmental functioning of soil and managing the soil heritage)".

${ }^{3}$ At the time, the major waste-water treatment plant in Achères processed $90 \%$ of the waste-water from Greater Paris.
}

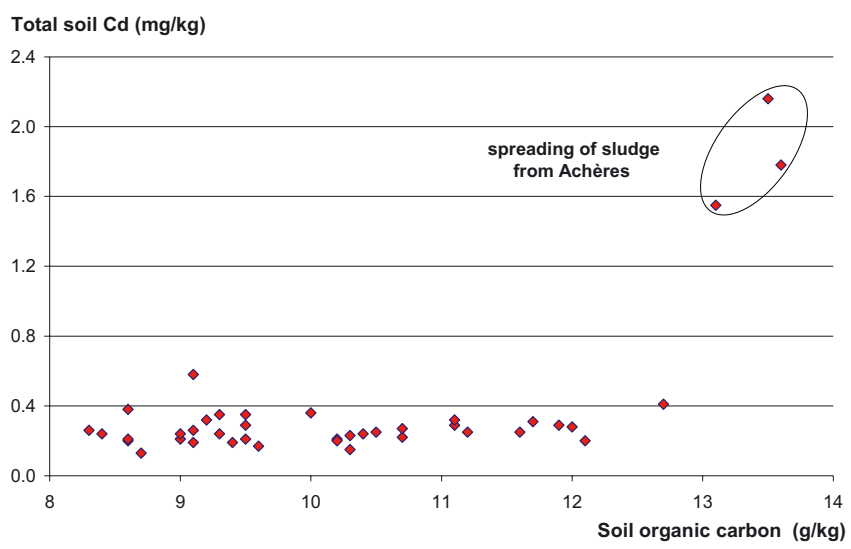

Figure 2. Cd versus soil organic carbon content for 39 surface-tilled horizons of a particular soil series (Luvisols developed in lœss in the Vexin area). There is no relation between the two variables, but the three sites where sludge was spread in the 1970s show a clear cadmium contamination and carbon enrichment.

on nearby agricultural land because it could be an interesting source of fertilisers. At the time - 1975 to 1986 - no surveillance or regulations existed for this type of practice, when quite large tonnages were spread in some cases. This sludge had such a good reputation as a fertiliser and humusrich amendment that it was then sold to farmers. Twenty-two non-experimental fields of the Vexin area were studied by Bernardon (1993), who calculated that during that period one to four sludge-spreading events contributed as much as 0.22 to $4.3 \mathrm{~kg}$ of Cd per ha, 6.5 to $40 \mathrm{~kg}$ of $\mathrm{Pb} / \mathrm{ha}, 28$ to $189 \mathrm{~kg}$ of $\mathrm{Zn} / \mathrm{ha}$, and 8 to $61 \mathrm{~kg}$ of $\mathrm{Cu} / \mathrm{ha}$.

Such an input obviously had a clear impact on the total trace metal contents of the receiving soils, especially on a particular soil series (luvisols developed in loess - Baize, 1997). Figure 2 shows that the three surface horizons of soil with a large volume of spread sludge have a much higher cadmium content than that usually observed in surface horizons of this soil series ( 1.55 to 2.16 versus 0.15 to $0.40 \mathrm{mg} / \mathrm{kg}$ ). The rare studies of wheat-grain quality, however, did not show a significant "before and after" difference in cadmium content (Bauvois et al., 1985; Tercé et al., 2002).

\subsection{The experiment in Bézu-le-Guéry}

Another example is the experiment run by the Agricultural Chamber of Aisne during the 1970s, when sludge from the Achères plant was spread over very hydromorphic silty soil near Bézu-le-Guéry in the Haute Brie area (Bauvois et al., 1985). In all, $208 \mathrm{t} / \mathrm{ha}$ of sludge, or $118 \mathrm{t}$ of dry matter (DM) per ha, was applied in two double-dose applications in 1974 and 1977. Knowing that the cadmium content of the sludge was $117 \mathrm{mg} \mathrm{Cd} / \mathrm{kg} \mathrm{DM}$, the quantity of cadmium thus spread can be estimated at $13.8 \mathrm{~kg} / \mathrm{ha}$, corresponding to an increase in the concentration of about $+3.5 \mathrm{mg} / \mathrm{kg}$ of the tilled surface horizon.

Such experimental conditions that applied huge quantities of metals had a major impact on the total cadmium contents of 
Table I. Bézu-le-Guéry field trial: Total trace metal contents of the surface horizons, measured in 1983 and 1993 (Bauvois et al., 1985; Ducaroir and Cambier, 1994).

\begin{tabular}{ccccccc}
\hline & \multicolumn{2}{c}{ Four plots with sludge } & \multicolumn{3}{c}{ Four control plots without } \\
& \multicolumn{3}{c}{$(118$ t/ha DM $)$} & \multicolumn{3}{c}{ sludge } \\
\hline & \multicolumn{2}{c}{1983} & 1993 & \multicolumn{2}{c}{1983} & 1993 \\
& min. & max. & mean & min. & max. & mean \\
\hline $\mathrm{Cd}$ & 2.47 & 3.38 & 3.06 & 0.09 & 0.21 & 0.12 \\
$\mathrm{Cr}$ & 56.6 & 67.7 & 70.4 & 27.2 & 37.6 & 27.0 \\
$\mathrm{Cu}$ & 42.0 & 52.5 & 49.2 & 7.0 & 9.2 & 7.3 \\
$\mathrm{Hg}$ & 0.29 & 0.35 & & 0.04 & 0.06 & \\
$\mathrm{Ni}$ & 16.0 & 20.4 & 19.8 & 11.5 & 15.1 & 11.1 \\
$\mathrm{~Pb}$ & 43.9 & 48.5 & 57.2 & 18.8 & 23.6 & 23.4 \\
$\mathrm{Zn}$ & 143 & 169 & 181 & 33 & 46 & 38 \\
\hline
\end{tabular}

the surface horizon (and also on the other metals - Tab. I). The average cadmium content of winter barley grains, grown on four plots with spread sludge and harvested in 1983 (six years after the last spreading), was $0.79 \mathrm{mg} / \mathrm{kg}$, whereas that of four control plots without spread sludge was only $0.33 \mathrm{mg} / \mathrm{kg}$ (Bauvois et al., 1985).

\subsection{First trials at the La Bouzule experimental farm (Lorraine)}

The experiment started in 1974 on $10 \mathrm{~m}^{2}$ plots (Morel and Guckert, 1984), where sludge from the city of Nancy (average cadmium content of $27 \mathrm{mg} / \mathrm{kg}$ ) was spread in 1974-75 and 1979 at doses between 30 and $340 \mathrm{t} / \mathrm{ha} \mathrm{DM}$, or cumulative quantities of cadmium varying from 0.81 to $9.18 \mathrm{~kg} / \mathrm{ha}$. The soil is silty-clayey over about the first $40 \mathrm{~cm}$, becoming more clayey and less permeable farther down.

In 1981, the sludge application had caused a significant increase in the total $\mathrm{Zn}, \mathrm{Cu}, \mathrm{Cd}$ and $\mathrm{Pb}$ contents of the tilled horizon. However, analysis of this surface horizon found only half of the total trace metal input. The presumably easily assimilated metal fractions were assayed by means of partial extraction with DTPA ${ }^{4}$, on soil samples taken on six dates between March 1979 and October 1981. The quantity of cadmium extracted with DTPA showed a linear relationship with the initially applied dose, as well as a regular decrease in the total contents over time. According to Morel and Guckert (1984), this would indicate that the metals evolve over time toward forms that are less easily mobilised (ageing).

\subsection{Experiments at the Couhins experimental farm (INRA, Bordeaux)}

This well-known French experimental site was set up in 1974. It resulted in many publications, the main ones being Juste and Solda, 1977; Legret et al., 1988; Gomez et al., 1992; Juste and Mench, 1992; and Bermond et al., 1998. The trial plots measured only 6 by $3 \mathrm{~m}$, and every treatment was repeated in four plots. The initial objective was to compare control plots that received the following: (i) only mineral fertiliser;

\footnotetext{
${ }^{4} \mathrm{DTPA}=$ diethylene triamine pentaacetic acid.
}

(ii) farm manure (with a Cd content of $0.70 \mathrm{mg} / \mathrm{kg} \mathrm{DM}$ ); (iii) sewage sludge from the plant in Ambarès; and (iv) sewage sludge from the "Louis Fargue" plant in Bordeaux.

The Ambarès (a small town of 9000 inhabitants) sludge represented "standard" (at the time) urban sludge. It contained $60 \mathrm{mg}$ of $\mathrm{Cd} / \mathrm{kg}$ and was spread at a rate of 10 and $100 \mathrm{t} / \mathrm{ha}$ DM every two years from 1974 to 1988. The Louis Fargue sludge was selected for its extraordinary cadmium (and nickel) content because of the presence of a battery factory upstream from the treatment plant. This plant, in fact, processed more industrial than simple urban waste-water. This sludge was spread three times, in 1976, 1978 and 1980 at rates of 10 and $100 \mathrm{t} / \mathrm{ha}$ DM. According to Legret et al. (1988), the maximum cadmium content was $2672 \mathrm{mg} \mathrm{Cd} / \mathrm{kg}$ for an average of $1830 \mathrm{mg} \mathrm{Cd} / \mathrm{kg}$ ). Gomez et al. (1992) reported the main features and results of this experiment. They calculated the cumulative cadmium quantities thus spread as:

Ambarès $-100 \mathrm{t} / \mathrm{ha} \times 8$ applications $\rightarrow 27$ kilograms of Cd per ha

Louis Fargue -100 t/ha $\times 3$ applications $\rightarrow 641$ kilograms of $\mathrm{Cd}$ per ha

The soil of the experimental plots is highly particular. Over at least $1 \mathrm{~m}$ depth, it contains only $4 \%$ clay and $>80 \%$ sand. Its initial $\mathrm{pH}$ was 5.3. Such sandy-gravelly soils are locally known as "grave" (Arenosols according to the WRB). The tested crop was irrigated maize. Soil properties and plant composition at different growth stages were regularly monitored.

Under these conditions, major impacts were observed in the plots that received a total of $300 \mathrm{t} / \mathrm{ha}$ of Louis Fargue sludge. Firstly, after the third application in 1980, a strong phytotoxic effect was observed on the maize yield, which decreased by half. Secondly, the cadmium concentration of the surface horizon determined in 1989 was $94.9 \mathrm{mg} / \mathrm{kg} \mathrm{DM}$ versus $<0.50$ before the launching of the trial. However, Gomez et al. (1992) calculated that about half of the cadmium input was no longer present in the first metre of soil! Part of this missing cadmium may have been evacuated laterally, linked with particles transported by runoff. The trial plots are indeed quite small and those serving as controls contained on average $1.3 \mathrm{mg} \mathrm{Cd} / \mathrm{kg}$ in 1989 , which is the evidence of a lateral transfer. Massive vertical losses through the soil should not be excluded either, in view of the sandy, quick filtering and acid character of this soil.

In 1976, in the plots that received two Louis Fargue sludge applications (i.e. $200 \mathrm{t} / \mathrm{ha} \mathrm{DM}$ ), the mature maize kernels contained $0.50 \mathrm{mg} \mathrm{Cd} / \mathrm{kg}$ vs. $0.17 \mathrm{mg} \mathrm{Cd} / \mathrm{kg}$ in the control plots and those with manure application (Juste and Solda, 1977).

These experiments supplied extravagant quantities of cadmium (up to $641 \mathrm{~kg} \mathrm{Cd} / \mathrm{ha}$ ) on an "extreme", very sandy and rather acid soil without any constituents that might fix the supplied trace metals. The impact of such spreading on this soil and the plants cultivated on it is thus not surprising. In the 1990s and more recently, the INRA researchers from Bordeaux have carried out many more experiments on the same plots, studying the best procedures for remediating such polluted soils by means of in situ immobilisation (e.g. Boisson et al., 1998; Mench et al., 2000, 2002). These old experimental plots today constitute a fascinating research laboratory, even 
though they do not represent today's reality of the spreading of sewage sludge on agricultural soil.

\section{SPREADING CADMIUM-RICH SEWAGE SLUDGE IN THE LIMOUSIN REGION}

In the Limousin region, crop rotation commonly consists of 4 to 5 years of temporary grassland, followed by maize for silage fodder and a cereal with straw. The soils in this region commonly being acid, a risk exists of transferring trace metals from topsoils to plants.

In the past, the sludge from some waste-water treatment plants had high cadmium content, e.g. $20.7 \mathrm{mg} / \mathrm{kg} \mathrm{DM}$ on average for one of them before 1998. The cadmium came mainly from industrial waste related to china manufacturing and decoration. Although since late 1999 such industrial effluents no longer affect sludge quality, the Agricultural Chamber of Haute-Vienne has still carried out a study of soil and softwheat-grain quality according to the protocol of the AGREDEQUASAR programme (Courbe et al., 2002). A total of 36 sites was studied, corresponding to soils developed in metamorphic rocks (leptynite, migmatite and gneiss), and to soils derived from diorite.

Four types of sites were distinguished in terms of cadmium quantities supplied by sludge spreading over the preceding 10 year period: 22 control sites without spreading; 2 sites that received less than $100 \mathrm{~g} \mathrm{Cd}$ per ha, designated below as "small quantities"; 4 sites on diorite that received between 100 and $300 \mathrm{~g} \mathrm{Cd}$ per ha, designated below as "moderate quantities"; and 8 sites that received between 500 and $600 \mathrm{~g} \mathrm{Cd}$ per ha, designated below as "large quantities", i.e. much more than the cumulative flow now authorised by the French regulation of January 1998 ( $150 \mathrm{~g} / \mathrm{ha}$ over 10 years). In fact, these fields probably received three times more cadmium over the past 30 years.

In this rural area of little intensive agriculture, any total cadmium content of soil $>0.40 \mathrm{mg} / \mathrm{kg}$ results probably from human-induced contamination. Of the 36 analysed soil samples, 11 values exceeded this threshold of $0.40 \mathrm{mg} / \mathrm{kg}$ and three contained between 1 and $2 \mathrm{mg} / \mathrm{kg}$ (not shown). Eight correspond to plots that received "large quantities" and two others to soils over diorite that received "moderate quantities".

In the wheat grains, 12 values are $\geqslant 0.11 \mathrm{mg} / \mathrm{kg} \mathrm{DM}$, the maximum concentration for cadmium in wheat grains as recommended by the Higher French Council for Public Health (CSHPF). Eight of these were measured in "large quantities" sites and three in "moderate quantities" sites, but this cadmium abundance in the wheat grains seemed to have no relationship with the soil $\mathrm{pH}$.

The soil samples were subjected to partial extraction with DTPA. The quantities of DTPA-extracted cadmium correlate well with the $\mathrm{Cd}$ contents measured in the grains (Fig. 3 - correlation coefficient $\mathrm{R}^{2}=0.71$ ). Beyond the threshold of $0.10 \mathrm{mg} / \mathrm{kg}$ extracted with DTPA, there is a high probability that the $\mathrm{Cd}$ concentration in the wheat grains will be equal to or higher than the recommended CSHPF value of $0.11 \mathrm{mg} \mathrm{Cd} / \mathrm{kg} \mathrm{DM}$.

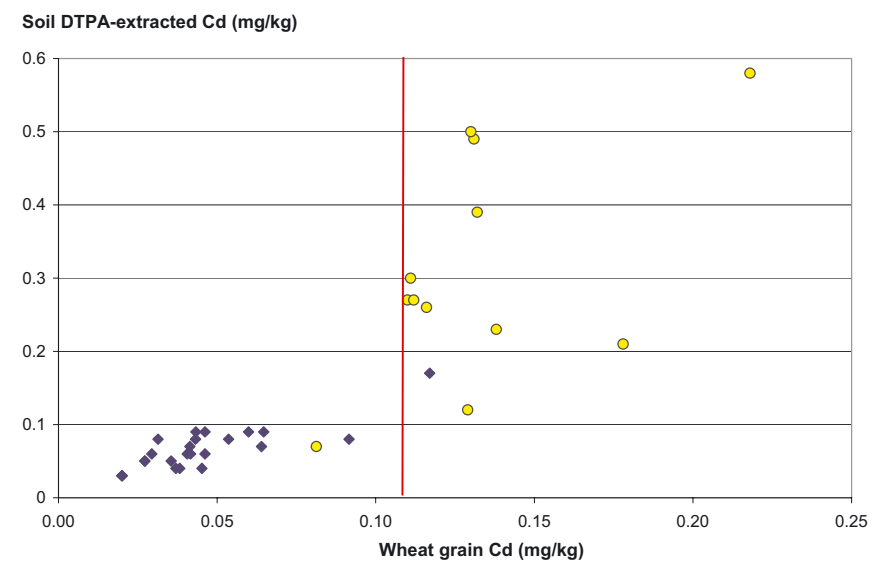

Figure 3. Soils of the Limousin region (36 tilled horizons). Relationship between cadmium extracted with DTPA from soil samples and cadmium assayed in wheat grains. "Moderate and large quantities" sites are shown by circles; diamonds represent the control sites and the two "small quantities" sites (Courbe et al., 2002). The red line corresponds to the French recommended maximal value.

The four soils developed from diorite which received moderate quantities of $\mathrm{Cd}$ have rather low cadmium contents at 0.22 to $0.47 \mathrm{mg} / \mathrm{kg}$, but $\mathrm{Cd}$ concentrations in the grains that are as high as those of the eight "large quantities" sites over metamorphic rocks $(0.08,0.13,0.14$ and $0.18 \mathrm{mg} / \mathrm{kg})$. This means that the exogenous cadmium brought to the diorite sites is phytoavailable for the wheat, notwithstanding a lower total content in the soil.

In conclusion, the study carried out in the Limousin shows that moderate spreading of sewage sludge containing cadmium quantities compatible with the new regulation (small quantities sites) does not show up in either the soil analyses or the wheat-grain analyses. However, any higher and continuous input of cadmium (moderate quantities sites over diorite and large quantities sites) clearly stands out in both soil and wheat-grain analyses.

The reader will have noted that this quite particular case belongs to the past. Though it is of scientific interest, it questions neither the rules laid down by French regulations, nor the reasonable spreading of urban sludge over agricultural land.

\section{SPREADING OF SEWAGE SLUDGE OVER FARMLAND COMPLYING WITH FRENCH REGULATIONS}

\subsection{AGREDE-QUASAR Research Programme (Baize et al., 2003)}

The AGREDE-QUASAR study by INRA in collaboration with several Agricultural Chambers took place over two periods. First, soil series were studied that had not received sewage sludge, or other urban waste. Located in rural areas, these soils had steadily received phosphate fertilisers and they were not sheltered from the possible little atmospheric deposition. 
Only two cultivars of soft wheat were studied (Trémie and Soissons), and the sampling strategy was soil series-oriented. The mature wheat ears were harvested over $1 \mathrm{~m}^{2}$ and over a widely separated dozen fields for each soil series, after which the trace metal contents of the grains were determined. On each grain-sampling site, the surface horizon of the soil was taken and characterised by in-depth analyses, including agropedological characterisation, total trace metal contents and partial extraction of the metals with three different reagents $\left(\mathrm{CaCl}_{2} 0.01 \mathrm{M}-\mathrm{NaNO}_{3} 0.1 \mathrm{M}\right.$ and $\left.\mathrm{NH}_{4} \mathrm{NO}_{3} 1 \mathrm{M}\right)$. This provided references for various soil series with "sludge-free" agriculture.

During the second period, in 1999, new sites covering the same soil series as before were studied following the same protocol, but which had received sewage sludge at rates in accordance with the current regulations at the time $(\mathrm{Cd}$ content of the sludge $<3.5 \mathrm{mg} / \mathrm{kg} \mathrm{DM}$, most often $<1.5$ ).

In all, 163 sites were studied, 33 of which were "with sludge", belonging to 11 contrasting soil types; these were soils developed over a large range of sedimentary rocks, including Quaternary silt, river terraces and marine sediments such as Cretaceous chalk and Jurassic limestone. The sampled fields were located in nine departments of the northern half of France.

In the framework of this programme, the composition of wheat grains could be compared with the analytical characteristics of the soil (surface horizon) where the wheat grows. In the rare other French studies, the analysed grain batches were selected by "production region", and nothing is known about the type and properties of the soils in which the wheat was grown.

The quantities of sludge spread over the trial plots as part of this programme were entirely reasonable and respected the regulations (Tab. IV). Cadmium input was estimated to be between 0.8 and $15 \mathrm{~g} / \mathrm{ha}$ for one or two spreading events.

Partial extraction with neutral salts was carried out on the soil samples, after which the extracted $\mathrm{Cd}, \mathrm{Cu}, \mathrm{Pb}$ and $\mathrm{Zn}$ were assayed.

The "with sludge" soil samples did not show any difference from the "sludge-free" ones. The $\mathrm{pH}$ was the main factor for explaining the quantities of extracted cadmium and zinc, the highest quantities being obtained for the lowest $\mathrm{pH}(<6.5)$. The reverse was true for copper, where the highest extracted quantities were obtained from certain samples with a $\mathrm{pH}$ of 8.0 or more. Most of the "with sludge" soil samples had a $\mathrm{pH}$ $>8.0$, but other soils that had the same range of $\mathrm{pH}$ values, but were "sludge-free", gave similar results (Baize et al., 2003).

During this study it was thus never possible to show a significant impact of sludge spreading on soil composition (based on partial extraction), or on that of the wheat grains. In the case of soil types with a natural tendency toward acidity (soils developed in sands or loess-like deposits), the highest cadmium contents of wheat grains occurred on soil with the lowest $\mathrm{pH}$, $<6.5$, as could be expected, because $\mathrm{pH}$ is the most important soil factor controlling cadmium uptake (Kirkham, 2006).
Table II. Cadmium and lead concentrations measured in the 12 elementary plots in Barneau before (1997) and after (2001) two sewage sludge applications.

\begin{tabular}{lcccc}
\hline & \multicolumn{2}{c}{ Cadmium } & \multicolumn{2}{c}{ Lead } \\
\hline Plot & $\begin{array}{c}\text { before } \\
\text { spreading } \\
(1997)\end{array}$ & $\begin{array}{c}\text { after } \\
\text { spreading } \\
(2001)\end{array}$ & $\begin{array}{c}\text { before } \\
\text { spreading } \\
(1997)\end{array}$ & $\begin{array}{c}\text { after } \\
\text { spreading } \\
(2001)\end{array}$ \\
\hline Control R1 & 0.279 & 0.300 & 88.6 & 47.9 \\
Control R2 & 0.267 & 0.280 & 45.9 & 100.1 \\
Control R3 & 0.269 & 0.280 & 39.7 & 65.5 \\
Control R4 & 0.300 & 0.300 & 53.7 & 70.4 \\
20 t/ha R1 & 0.359 & 0.320 & 32.0 & 38.7 \\
20 t/ha R2 & 0.271 & 0.320 & 47.4 & 63.7 \\
20 t ha R3 & 0.305 & 0.360 & 43.4 & 83.1 \\
20 t/ha R4 & 0.321 & 0.300 & 53.1 & 52.1 \\
60 t/ha R1 & 0.277 & 0.340 & 36.1 & 43.4 \\
60 t/ha R2 & 0.286 & 0.350 & 67.4 & 55.4 \\
60 t/ha R3 & 0.319 & 0.370 & 52.1 & 120.7 \\
60 t/ha R4 & 0.327 & 0.340 & 48.4 & 55.6 \\
\hline
\end{tabular}

\subsection{Difficulties of soil monitoring - The Barneau and Bouy experiments (SEDE (1999-2003))}

Identical protocols were adopted on two experimental sites in Barneau (Brie Plateau, thick luvisol), and in Bouy ("Champagne crayeuse", hyper-calcareous chalk-derived soil). Unlimed sewage sludge from the Valenton plant was spread over the trial sites in September 1997 and the autumn of 1999. The sludge contained on average $5.4 \mathrm{mg} \mathrm{Cd} / \mathrm{kg} \mathrm{DM}$. Soft wheat was harvested in 1999 and 2001.

Each trial site comprised 12 plots of 40 by 9 m subjected to four repetitions (coded R1 to R4) of three applications:

(i) Control plot fertilised with superphosphate 45;

(ii) $\mathrm{D} 1=$ Normal sludge dose of $6 \mathrm{t} \mathrm{DM} / \mathrm{ha}$ );

(iii) $\mathrm{D} 3=$ Triple dose of $18 \mathrm{tDM} / \mathrm{ha}$.

(iv) A composite sample of 10 samples was taken on each plot before sludge application. After application, the samples consisted of 15 composites, systematically taken at depths of 0-30, 30-60 and 60-90 cm.

This experiment provided a good opportunity for highlighting the difficulties of this type of diachronic monitoring of trace metal contents in soil, in this case between the "initial state" measurements made in 1997 and, after two sludge applications, in August 2001.

The cadmium quantities supplied by the two applications were evaluated at 64 to $112 \mathrm{~g} / \mathrm{ha}$ for the D1 applications and 228 to $268 \mathrm{~g} /$ ha for the D3 ones, theoretically corresponding to an increase in the concentration of 0.016 to $0.068 \mathrm{mg} / \mathrm{kg}$ (calculated for a 30-cm-thick tilled horizon with an apparent density of 1.3 , weighing $3900 \mathrm{t} / \mathrm{ha}$ ). Such a low theoretical increase remains within the order of magnitude of analytical uncertainty and of the spatial variability earlier introduced by different agricultural practices.

Moreover, in Barneau the experimental terrain did not have homogeneous initial TM values. When starting the trial in 
Table III. Average zinc contents in wheat grains in Barneau and Bouy (in $\mathrm{mg} / \mathrm{kg}$ ).

\begin{tabular}{lcccc}
\hline & \multicolumn{2}{c}{ Barneau } & \multicolumn{2}{c}{ Bouy } \\
\hline & 1999 & 2001 & 1999 & 2001 \\
Control & 22.9 & 23.1 & 17.5 & 20.2 \\
D1 & 23.9 & 25.8 & 19.6 & 23.5 \\
D3 & 25.1 & 30.6 & 21.2 & 27.7 \\
CV \% & 7.4 & 8.1 & 7.1 & 5.4 \\
Signif. level & NS & HS & S & HS \\
\hline
\end{tabular}

1997, the total lead contents of the 12 plots varied between 32 and $89 \mathrm{mg} / \mathrm{kg}$ (Tab. II).

Another point is that there were incoherencies between the soil analyses of the individual plots before and after sludge application. For instance, in some cases the $\mathrm{Cd}$ and $\mathrm{Pb}$ concentrations measured in Bouy and the $\mathrm{Pb}$ contents in Barneau were lower in 2001 than the 1997 values. Moreover, the strong $\mathrm{Pb}$ content increases in the Barneau control plots between 1997 and 2001 are inexplicable as no sewage sludge was spread over these plots (Tab. II).

This discrepancy might be due to the systematic sampling over a constant thickness of $30 \mathrm{~cm}$, which, because of the variable compactness of soil over time, might not always correspond to the true thickness of the tilled surface horizon. In 2001 , the $0-30 \mathrm{~cm}$ layer may well have corresponded to $28 \mathrm{~cm}$ of tilled horizon $+2 \mathrm{~cm}$ of underlying soil, much less enriched in cadmium, lead and other metals, thus explaining the lower values than those of 1997. In Bouy, this might explain why the average $\mathrm{CaCO}_{3}$ content of soil measured in 2001 was $10 \%$ higher than the 1997 value (76\% instead of $66 \%$ for the control plots). By sampling to $30 \mathrm{~cm}$ depth in 2001, the top of a more chalky horizon than the tilled one may have been included.

It is thus clear that, when sampling, one should respect the lower limit of the tilled horizon, rather than sampling at systematic increments that commonly do not correspond to field reality.

The average compositions of wheat grains harvested in 1999 and 2001 from the three types of trial plots on both sites show no significant differences in Barneau (all Cd values $<0.05$ ) or in Bouy (all Cd values $<0.04$ ), regardless of the year and even after triple sludge doses (D3). However, significant differences occur for zinc (Tab. III).

\subsection{Other experiments}

A national inventory lists 136 agronomic experiments in France that tested the interest and impact of various residual organic and mineral substances. Not all covered trace metals and some did not concern large-scale farming. Baize et al. (2006) succinctly described eight experiments, all implemented after 1995, some elements of which are shown in Table IV. The soils tested are of different types and the experimental design can be rather simple or quite complex and thorough. The cadmium input varied strongly between trials and even within a single trial, though always remaining between 0.5 and $88 \mathrm{~g} / \mathrm{ha}$. None of the experiments showed a noticeable effect of sludge application on crop quality. Figure IV provides a good example. Deléan and Kockmann (2003) studied a set of experimental fields in Burgundy and Franche-Comté belonging to various soil types: 15 parcels having never received sludge before were subjected to sludge application on half of their surface, the other half being used as a control plot. Thirteen parcels spread with one or several spreadings during the previous five years were also investigated. Analyses of topsoils and wheat grains were carried out $(n=43)$.

Obviously, no link exists between the cadmium content of grains and the Cd quantity provided via sewage-sludge application. Differences observed in grains result much more from the soil properties, such as $\mathrm{pH}$, texture, or Fe and Mn oxyhydroxide abundance, and from the cultivar grown.

\section{CONCLUSION}

First, a major point should be highlighted: the phrase "sewage-sludge application on farmland" does not do justice to the possible colossal differences in metal-quantity input. Such differences depend upon different circumstances, such as the cumulative tonnage that was applied and the sludge composition, which has shown large variations over time and space. Table IV shows the input of estimated cadmium quantities for the various trials described in this paper. Such quantities go from $<1 \mathrm{~g} \mathrm{Cd} / \mathrm{ha}$ (sludge from small plants with minor trace metal content, spread in little quantities), to $4320 \mathrm{~g}$ $\mathrm{Cd} / \mathrm{ha}$ (four applications of sludge from the Achères plant in the 1970s and '80s). Worse, in the case of the experiment in Bézu-le-Guéry, two "double-dose" applications supplied 13.8 $\mathrm{kg} \mathrm{Cd} / \mathrm{ha}$, and the maximum quantity was reached in Couhins Louis Fargue with $641 \mathrm{~kg} \mathrm{Cd} / \mathrm{ha}$ !

This illustrates the importance of always evaluating as precisely as possible the real input of trace metal quantities from sludge applications, and to compare this with figures from other types of input, such as phosphate fertiliser, compost or manure.

In this respect, it is instructive to note that the U.S. Environmental Protection Agency limits to $18.4 \mathrm{~kg} / \mathrm{ha}$ the cumulative quantity of cadmium that can be applied to field crops, whereby the cadmium content of the sludge cannot exceed $85 \mathrm{mg} / \mathrm{kg}$, or $39 \mathrm{mg} / \mathrm{kg}$ to be considered as a "high-quality" biosolid (U.S. EPA, 1993). It is clear that the French and European authorities are much more severe than the U.S. Agency.

It is commonly very difficult to measure the impact of sludge applications on soil. Today, in France, the input of cadmium is very low to minute, which means that any $\mathrm{Cd}$ increases in the surface horizon often are smaller than analytical uncertainty. In this respect, it is useful to remember that:

- To increase a trace metal concentration by $1 \mathrm{mg} / \mathrm{kg}$ in a tilled horizon weighing between 3600 and 3900 tonnes/ha, the input of this trace metal must be 3.6 to $3.9 \mathrm{~kg} / \mathrm{ha}$.

- Therefore, the input of $100 \mathrm{~g}$ cadmium per hectare theoretically will increase the average $\mathrm{Cd}$ content of the receiving tilled horizon by only about $0.028 \mathrm{mg} / \mathrm{kg}$, which is obviously of the same order as analytical uncertainty. 
Table IV. Estimated cadmium quantities reported from experiments presented or mentioned in Baize et al. (2006) (expressed as g/ha). Comparison with regulation fluxes and amounts supplied by phosphate fertilisation.

\begin{tabular}{|c|c|c|c|c|c|c|}
\hline \multirow{2}{*}{ Before 1990} & \multirow[t]{2}{*}{ Study } & \multirow[t]{2}{*}{ years } & \multirow{2}{*}{$\begin{array}{c}\text { Waste-water } \\
\text { treatment plant }\end{array}$} & \multirow{2}{*}{$\begin{array}{c}\text { Number of } \\
\text { spreading events }\end{array}$} & \multicolumn{2}{|c|}{ Cd quantities $\mathrm{g} / \mathrm{ha}$} \\
\hline & & & & & minimum & maximum \\
\hline \multirow[t]{3}{*}{ Experiments } & Couhins - sludge from Louis Fargue & $1970 \mathrm{~s}$ & Bordeaux & 3 & & 641000 \\
\hline & La Bouzule (1974-1981) & 1970-80s & Nancy & 2 & 810 & 9180 \\
\hline & Bézu-le-Guéry & 1970s & Achères & 2 & & 13800 \\
\hline Field reality & Vexin (Bernardon, 1993) & $1970-80$ s & Achères & 1 to 4 & 220 & 4320 \\
\hline \multirow[t]{3}{*}{ Limousin } & Limousin small quantities & $1990 \mathrm{~s}$ & Limousin & over 10 years & $<100$ & $<100$ \\
\hline & Limousin moderate quantities & $1990 \mathrm{~s}$ & Limousin & over 10 years & 100 & 300 \\
\hline & Limousin large quantities & $1990 \mathrm{~s}$ & Limousin & over 10 years & 500 & 600 \\
\hline \multirow[t]{6}{*}{ Others } & Barneau \& Bouy - simple rate & $1990 \mathrm{~s}$ & Valenton & 2 & 64 & 112 \\
\hline & Barneau \& Bouy - triple rate & $1990 \mathrm{~s}$ & Valenton & 2 & 228 & 268 \\
\hline & Colmar & 2000 s & local & 3 in 5 years & 11 & 23 \\
\hline & La Bouzule (after 1996) & 1990-2000 & local & 4 in 7 years & 50 & 88 \\
\hline & Poucharramet (wheat) & $2000 \mathrm{~s}$ & Toulouse & 3 & 2 & 18 \\
\hline & City of Mayenne & $2000 \mathrm{~s}$ & Mayenne & 3 in 5 years & & 17.6 \\
\hline \multirow[t]{4}{*}{ Legal thresholds } & U.S. EPA - field crops & & & cumulative & & 18400 \\
\hline & European regulation 86/278/CEE 1986 & & & over 10 years & & 1500 \\
\hline & French regulation - until 01/01/2001 & 1990-2000s & & over 10 years & & 300 \\
\hline & French regulation - from 01/01/2001 on & $2000 \mathrm{~s}$ & & over 10 years & & 150 \\
\hline$P$ fertilisers & Amounts supplied by phosphate fertilisers & & & over 10 years & 3 & 60 \\
\hline
\end{tabular}

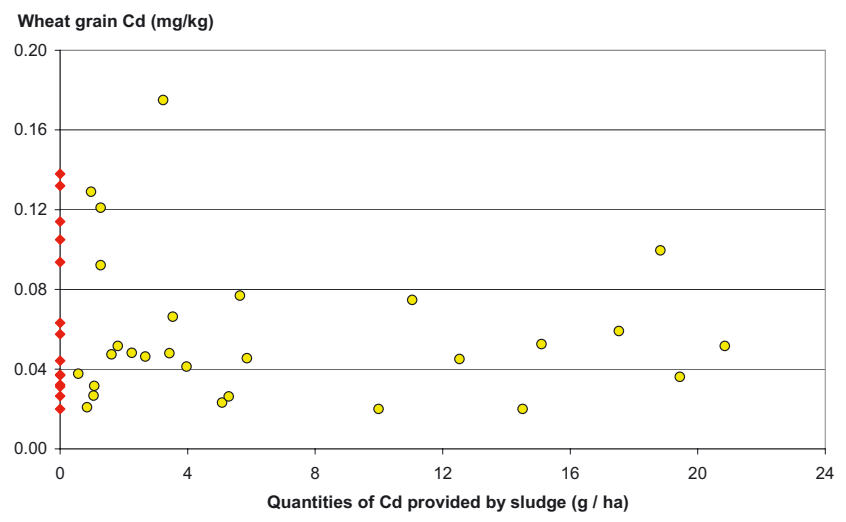

Figure 4. Trials in Burgundy and Franche-Comté (Deléan and Kockmann, 2003). Relationship between cadmium content in wheat grains and $\mathrm{Cd}$ quantities provided by sewage-sludge application $\left(\mathrm{R}^{2}=-0.016\right)$. Cadmium input in 15 control plots is nil.

Quantifying the impact of sludge spreading on the chemical composition of consumed organs of plants is not easy either. This kind of analysis is difficult to perform and only a few laboratories are able to carry out such analyses with good reliability.

Another, commonly ignored, difficulty is that many experimental fields are pedologically heterogeneous, at least as far as their initial trace metal content is concerned. This is often discovered afterwards. Other problems, equally difficult to identify, such as those related to sampling, sample processing, or analytical work, can again generate absurd postsludge-application analytical results when compared with the pre-application ones. Generally, such results are clearly unrelated, being far too high or much too low, compared with the real input of trace metal quantities.

Where trace metal input quantities were enormous (Couhins, Bézu-le-Guéry, first trials in La Bouzule, and Vexin in the 1970s and '80s), quite clear impacts are visible. These appear in the total metal contents of soils, in the quantities of metals recovered by partial extraction, and in the composition of certain plant organs. Where cadmium input is small and compatible with the requirements of French legislation, it is impossible to demonstrate even the slightest impact on soil or crops. In fact, this is quite reassuring, at least in the short term. The main merit of 1998 French regulation of sewage-sludge application has thus been to greatly decrease the trace metal input into soils. For the most part, this aim was reached.

However, several difficulties remain. First of all, not enough time has passed to have a long-term view of the impact of sewage-sludge application at a reasonable rate. It is clearly difficult to extrapolate the results from short-term experiments -4 to 15 years as a maximum - to evaluate the impact of such spreading in the long term. In addition, much more work has to be done on other food crops such as spinach, cabbage and salads, which accumulate trace metals more easily than wheat grains. 
The best way to evaluate the possible transfer from soil to plants is to carry out direct analyses of specific organs of the harvested plants. However, such analyses are expensive and delicate, posing problems for many analytical laboratories. This is the main interest of partial extraction with neutral salts or complexing reagents (EDTA, DTPA) on soil samples, in order to make a best-possible estimate of phytoavailability or mobility of trace metals (Baize and Tomassone, 2003, 2005).

Finally, it should be stressed that the $\mathrm{pH}$ of the receiving soil is a major factor influencing the risk of trace metal transfer and especially of cadmium in soil toward plants; the lower the $\mathrm{pH}$, the higher the risk of phytoavailability and mobility. Fortunately, farmers can easily control this parameter in the medium term by regular application of alkaline calcic amendments.

In fact, limed sludge carries its own antidote against contained trace metals, by increasing the $\mathrm{pH}$ of the receiving soils and thus decreasing the potential for mobility and phytoavailability of potentially dangerous metals, at least in the short term. However, the problem is what happens when naturally acid agricultural land, amended with sewage sludge, is abandoned. A progressive re-acidification might lead to desorption and liberation of the metals.

As a last point, we should stress the role played by certain natural soil constituents as powerful trace metal adsorbers. These include organic matter, clay minerals, and especially iron and manganese oxyhydroxides. Different soil series do not present the same capacity of trace metal retention, according to the relative abundance of such constituents in all their horizons, not only in the topsoil. Their vulnerability is thus highly variable and merits being taken into account in order to plan an optimal location of sewage-sludge spreading.

\section{REFERENCES}

AFNOR (1996) Qualité des sols. Mise en solution totale par attaque acide, Norme NF X 31-147.

Baize D. (1997) Teneurs totales en éléments traces métalliques dans les sols (France), Références et stratégies d'interprétation, Chap. 25 et 27, INRA Éditions, Paris, 410 p.

Baize D., Tomassone R. (2003) Modélisation empirique du transfert du cadmium et du zinc des sols vers les grains de blé tendre, Étude et Gestion des Sols 4, 219-238.

Baize D., Tomassone R. (2005) Prédiction de la teneur en cadmium du grain de blé tendre à partir de mesures sur échantillons de sols, Journées techniques "Transfert des polluants des sols vers les végétaux cultivés et les animaux d'élevage", ADEME Paris, pp. 5-14.

Baize D., Deslais W., Gaiffe M. (1999) Anomalies naturelles en cadmium dans les sols de France, Étude et Gestion des Sols 2, 85-104.

Baize D., Mench M., Sappin-Didier V., Mocquot B., Gomez A., Proix N., Sterckeman T. (2003) Phytodisponibilité des éléments traces métalliques dans les grains de blé, Les Dossiers de l'environnement de l'INRA 25, 45-62.

Baize D., Courbe C., Suc O., Schwartz C., Tercé M., Bispo A, Sterckeman T., Ciesielski H. (2006) Épandages de boues d'épuration urbaines sur des terres agricoles : impacts sur la composition en éléments en traces des sols et des grains de blé tendre, Le Courrier de l'Environnement de l'INRA 53, 35-61.

Bauvois F., Ireland-Ripert J., Ducauze C. (1985) Évaluation du degré de contamination des sols et des cultures consécutive à des épandages de boues d'Achères, INA - Agence de bassin Seine-Normandie, SIAAP, 189 p.

Bergkvist P., Jarvis N., Berggren D., Carlgren K. (2003) Long-term effects of sewage sludge applications on soil properties, cadmium availability and distribution in arable soil, Agr. Ecosyst. Environ. 97, 167-179.

Bermond A. (1999) Caractérisation chimique de la spéciation des métaux traces dans les sols, in: Spéciation des métaux dans le sol, Club Crin Environnement, pp. 73-95.

Bermond A., Yousfi, I., Ghestem, J.-P. (1998) Kinetic approach to the chemical speciation of trace metals in soils, Analyst 123, 785-789.

Bernardon E., (1993) Analyse critique de l'utilisation des boues dans le Vexin ; problèmes posés par les éléments traces, Mémoire DEA, INA-Paris Grignon \& Univ. Paris VI et XI.

Boisson J., Mench M., Sappin-Didier V., Solda P., Vangronsveld J. (1998) Short-term in situ immobilization of $\mathrm{Cd}$ and $\mathrm{Ni}$ by beringite and steel shots application to long-term sludged plots, Agronomie 18, 347-359.

Cattani I., Romani M., Boccelli R. (2008) Effect of cultivation practices on cadmium concentration in rice grain, Agron. Sustain. Dev. 28, 265-271.

Courbe C., Baize D., Sappin-Didier V., Mench M. (2002) Impact de boues d'épuration anormalement riches en cadmium sur des sols agricoles en Limousin, Actes des Journées Nat. Étude des Sols, Orléans, pp. 15-16.

Deléan M.P., Kockmann F. (coord.) (2003) Programme de recherche de références relatives au recyclage agricole des boues en Bourgogne et Franche-Comté, Chambre d'agriculture de Saône et Loire, 69 p.

Ducaroir J., Cambier P. (1994) Distribution of Sludge-borne Trace Metals in a soil profile after long-term Application compared with the Geochemical background, Transactions 15th World Congress of Soil Science, Vol. 3b, 408-409.

Gomez A., Solda P., Lambrot C., Wilbert J., Juste C. (1992) Bilan des éléments-traces métalliques transférés dans un sol sableux après 16 années d'apports continus et connus de boues de station d'épuration et de fumier de ferme en monoculture irriguée de maïs, Conv. Recherche $\mathrm{n}^{\circ}$ 89-256, INRA, Bordeaux, 58 p.

Juste C., Solda P. (1977) Effets d'applications massives de boues de stations d'épuration urbaines en monoculture de maïs : actions sur le rendement et la composition des plantes et sur quelques caractéristiques du sol, Science du Sol 3, 147-155.

Juste C. Mench M. (1992) Long-term application of sewage sludge and its effect on metal uptake by crops, in: Adriano D.C. (Ed.), Biochemistry of trace metals, Lewis publishers, Boca Raton, pp. 159-193.

Kirkham M.B. (2006) Cadmium in plants on polluted soils: Effects of soil factors, hyperaccumulation, and amendments, Geoderma 137, $19-32$.

Legret M., Divet L., Juste C. (1988) Movement and speciation of heavy metals in a soil amended with sewage sludge containing large amount of Cd and Ni, Water Res. 22, 953-959.

McBride M.B., Berrett K.A., Kim B., Hale B. (2006). Cadmium sorption in soils after 25 years after amendment with sewage sludge, Soil Sci. 171, 21-28.

McGrath S.P., Zhao F.J., Dunham S.J., Crosland A.R., Coleman K. (2000) Long-term changes in the extractability and bioavailability of zinc and cadmium after sludge application, J. Environ. Qual. 29, 875883.

Meers E., Unamuno V., Vandegehuchte M., Vanbroekhoven K., Geebelen W., Samson R., Vangronsveld J., Diels L., Ruttens A., Du Laing G., 
Tack F. (2005) Soil-solution speciation of Cd as affected by soil characteristics in unpolluted and polluted soils, Environ. Toxicol. Chem. 24, 499-509.

Mench M., Manceau A., Vangronsveld J., Clijsters H., Mocquot B. (2000) Capacity of soil amendments in lowering the phytoavailability of sludge-borne zinc, Agronomie 20, 383-397.

Mench M., Solda P., Vangronsveld J. (2002) Conséquences sur le transfert de $\mathrm{Cd}$ et $\mathrm{Ni}$ dans le grain de maïs cinq ans après un traitement de réhabilitation, pp. 409-419, in: Baize D., Tercé M. (Eds.), "Les Éléments traces métalliques dans les sols - Approches fonctionnelles et spatiales", INRA Éd., Paris, 570 p.

Morel J.L., Guckert A. (1984) Évolution en plein champ de la solubilité dans DTPA des métaux lourds du sol introduits par des épandages de boues urbaines chaulées, Agronomie 4, 377-386.

Nirel P.M.V., Morel F.M.M. (1990) Pitfalls of sequential extractions, Water Res. 24, 1055-1056.

Rieuwerts J.S., Thornton I., Farago M.E., Ashmore M.R. (1998a) Factors influencing bioavailability in soils: preliminary investigations for the development of a critical loads approach for metals, Chem. Spec. Bioavailab. 10, 61-75.

Rieuwerts J.S., Thornton I., Farago M.E. and Ashmore M.R., (1998b). Quantifying the influence of soil properties on the solubility of metals by predictive modelling of secondary data. Chemical Spec. Bioavailab. 10, 83-94.
Schaub A. (2004) Site de références d'Ensisheim. Suivi des éléments et composés traces en monoculture de maïs suite à des épandages de boues urbaines chaulées ou non, Rapport 2003, ARAA, Colmar, $73 \mathrm{p}$.

SEDE (1999-2003) Impact du recyclage agricole des boues d'épuration urbaine sur la qualité des productions betteravières et céréalières, SEDE, avec le concours financier du SIAAP, de l'ADEME et de l'Agence de l'Eau Seine-Normandie, Divers documents.

Tack F.M., Verloo M.G. (1995) Chemical speciation and fractionation in soil and sediment heavy metal analysis: a review, Int. J. Environ. An. Ch. 59, 225-238.

Tercé M., Morel J.L., Baize D., Bermond A., Bourgeois S., Cambier P., Gaultier J.-P., Lamy I., Mench M., Mocquot B., Moisan H. (2002) Devenir du cadmium apporté par des épandages de boues urbaines en céréaliculture intensive, pp. 455-469, in: Baize D., Tercé M. (Eds.), "Les Éléments traces métalliques dans les sols - Approches fonctionnelles et spatiales", INRA Éditions, Paris, 570 p.

Ure A.M. (1991) Trace element speciation in soils, soil extracts and solutions, Microchim. Acta 104, 49-57.

U.S. Environmental Protection Agency (1993) Standards for the use or disposal of sewage sludge, Fed. Reg. 58, 9248-9415.

Wani P.A., Khan M.S., Zaidi A. (2007) Cadmium, chromium and copper in greengram plants Agron. Sustain. Dev. 27 145-153.

Wahid A., Ghani A., Javed F. (2008) Effect of cadmium on photosynthesis, nutrition and growth of mungbean, Agron. Sustain. Dev. 28, $273-280$. 